DANUTA JANCZEWSKA

Społeczna Akademia Nauk, Łódź, Polska

\title{
Logistyczno-marketingowe uwarunkowania transferu wiedzy w sektorze mikroprzedsiębiorstw
}

\section{The Logistics and Marketing Conditions of Knowledge Transfer in the Micro-enterprise Sector}

\begin{abstract}
Streszczenie: Transfer wiedzy ze sfery nauki do sfery przemysłu i usług jest obecnie przedmiotem zainteresowania zarówno jednostek naukowych, jak i przedsiębiorstw przemysłowych i usługowych, zwłaszcza w kontekście budowy gospodarki opartej na wiedzy (GOW). Celem referatu jest prezentacja wpływu działań logistyczno-marketingowych na proces dyfuzji wiedzy ze sfery nauki do sektora mikroprzedsiębiorstw. Zaprezentowano podstawy teoretyczne transferu wiedzy oraz jego efekty w mikroprzedsiębiorstwach w branży konstrukcji stalowych. W referacie poszukiwano odpowiedzi na pytanie czy elementy logistyczno-marketingowe mogą stać się stymulatorem aktywności mikroprzedsiębiorstw w szerokim spektrum funkcjonowania tychże przedsiębiorstw. Uwarunkowania logistyczno-marketingowe oraz efekty transferu wiedzy analizowano na podstawie badanej grupy mikroprzedsiębiorstw.
\end{abstract}

\begin{abstract}
The knowledge transfer from science into the business and service sector is now the point of interest for institutions of science and business units, especially in the context of building a knowledge-based economy. In Poland there is a lot of research prepared by government institutions such as Ministry of Economy and PARP (Polish Agency of Enterprise Development), and by UE. There is not so much research of micro-enterprises in the SMEs sector. The specificity of management of micro-enterprises has a big influence on the knowledge transfer process and recognizing the stimulating factor contributes to the growth of significance of transfer process in micro-enterprises. The aim of the present article is the presentation of logistics and marketing conditions of knowledge transfer process, especially in steel-construction branch. There are presented the author's own research of knowledge transfer in production and service providing enterprises in the steel-construction branch.
\end{abstract}

Słowa kluczowe: transfer wiedzy, mikroprzedsiębiorstwo, logistyka, marketing

Key words: the knowledge transfer, micro-enterprise, logistics, marketing 


\section{WSTĘP}

Badania nad problematyką usprawniania transferu wiedzy prowadzone są w Polsce przez instytucje rządowe, w tym Ministerstwo Gospodarki oraz PARP. Są one realizowane również w Unii Europejskiej. Wśród opracowań dotyczących sektora MSP w Polsce niewiele jest badań obejmujących przedsiębiorstwa mikro, zarówno produkcyjnych, jak i usługowych w aspekcie uwarunkowań logistyczno-marketingowych. Pojęcie i definicja wiedzy nie są jednoznacznie interpretowane w literaturze przedmiotu. W sposób precyzyjny są natomiast objaśniane poszczególne kategorie wiedzy, na przykład wiedza techniczna, czy medyczna - rozumiane jako ogólna wiedza specjalistyczna, dotycząca poszczególnych obszarów. Wiedzę tworzą zbiory danych, informacji i doświadczeń charakteryzujących się określoną użytecznością ${ }^{1}$. Rozwój przedsiębiorstw opartych na wiedzy zależeć będzie od jej zasobów oraz umiejętności implementacji wiedzy². Przedsiębiorstwa te powinny charakteryzować się następującymi cechami:

- planować swój przyszły rozwój,

- przewidywać wydatki związane z nabyciem lub tworzeniem nowej wiedzy,

- oszacować swój własny potencjał innowacyjny,

- być przygotowane na rosnącą konkurencję krajową i międzynarodową ze strony innych przedsiębiorstw opartych na wiedzy.

Unia Europejska przywiązuje dużą wagę do zagadnienia transferu wiedzy - o czym świadczy fakt, iż w kwietniu 2008 roku Komisja Europejska opublikowała zalecenia dotyczące zarządzania własnością intelektualną w procesie transferu wiedzy, a także kodeks dobrych praktyk dla uniwersytetów i publicznych jednostek naukowych. Transfer wiedzy z uczelni do przemysłu określony został w tym dokumencie jako strategiczna misja jednostek nauki względem społeczeństwa i tam, gdzie nowa wiedza powstała z wykorzystaniem środków publicznych, powinien być zapewniony wolny dostęp do wyników badań, z zachowaniem ochrony własności intelektualnej3. W niniejszym artykule rozpatrywane będzie zagadnienie dotyczące spektrum transferu wiedzy, interpretowanego w ujęciu procesowym.

${ }^{1}$ Zasób samych informacji nie stanowi zbioru wiedzy, gdyż stanowi zbiór nieuporządkowany i niecelowy, dopiero interpretacja i uporządkowanie zbioru informacji może być uważana za wiedzę - co potwierdza Marzena Anna Weresa w publikacji Wiedza jako przedmiot transferu do biznesu, [w:] Transfer wiedzy z nauki do biznesu doświadczenia regionu Mazowsze, red. M.A. Weresa, Wyd. SGH, Warszawa 2007, s. 28.

${ }^{2}$ Szerzej na temat działań przedsiębiorstw opartych na wiedzy w: L. Białoń, D. Janczewska, Wiedzochłonność procesów innowacyjnych, cz. II, „Postępy Techniki Przetwórstwa Spożywczego”, Nr 2/2007, t. 17/31, s. 93.

3 Commission Recommendation on The Management of Intellectual Property in Knowledge Transfer Activities and Code of Practice for Universities and Other Public Research Organizations, Commission of the European Communities, Brussel 10.04.2008. 
PoJĘCIE TRANSFERU WIEDZY

Istnieje wiele poglądów na istotę wiedzy będącej zasobem przedsiębiorstwa, utożsamianej z kapitałem intelektualnym (Intellectual Capital). T.A. Steward twierdzi, iż IC jest to wiedza, inteligentna materia, informacje, własności intelektualne, doświadczenie - które to elementy mogą wpływać na kreowanie nowych wartości (Steward 1997). Wiedza i kapitał intelektualny oraz skuteczne zarządzanie nimi stanowią obecnie czynniki sukcesu współczesnej organizacji. Uważa się, iż wiedza i kapitał intelektualny pracowników są najważniejszymi czynnikami produktywności (Probst, Raub, Romhard 2002: 9). Kapitał intelektualny w przedsiębiorstwie uczącym się może być traktowany jako zasób przedsiębiorstwa, a proces tworzenia kapitału może być zdefiniowany w ujęciu procesowym. W organizacji inteligentnej proces ten ma charakter ciągły i wiąże się z monitorowaniem efektów procesu w organizacji.

Metody pomiaru proponowane w literaturze przedmiotu dotyczą przedsiębiorstw dużych (Edvinsson, Malone 2001: 34), czego przykładem może być model Scandii opracowany w celu wyceny kapitału intelektualnego przedsiębiorstw przez skandynawskie przedsiębiorstwo ubezpieczeniowe Scandia. W modelu tym oszacowanie zasobów kapitału intelektualnego stało się punktem wyjścia do dalszych analiz (Edvinsson, Malone 2001: 56). Metoda pomiaru zwana Nawigatorem Scandii jest skomplikowana i niezbyt przystająca do zastosowania w przedsiębiorstwach MSP, zwłaszcza w mikroprzedsiębiorstwach. Z kolei model duński opracowany przez Ministerstwo Handlu i Przemysłu oraz Duńską Agencję Handlu i Przemysłu definiuje diagnozę kapitału intelektualnego poprzez ocenę zasobów przedsiębiorstwa oraz ocenę efektów i propozycje działań (Bukowitz, Wiliams 2000: 252). Rezultaty diagnozy opartej na modelu duńskim koncentrują się wokół efektów niematerialnych, takich jak: satysfakcja, lojalność, doświadczenie, których wzrost prowadzi do wzrostu wartości przedsiębiorstwa. Model duński może być zastosowany do zarządzania kapitałem intelektualnym w firmie MŚP ze względu na jego uniwersalny zakres oraz możliwość dostosowania do realiów małej firmy. Podejście oparte na tym modelu wymaga opisu stanu dzisiejszego w przedsiębiorstwie, wyboru właściwych działań oraz prezentacji i pomiaru rezultatów (Pietruszka-Ortyl 2002: 63).

\section{WARTOŚCIOWANIE WIEDZY W MIKROPRZEDSIĘBIORSTWIE}

Wartościowanie wiedzy i kapitału intelektualnego w organizacji jest przedmiotem wielu badań. Przyjmowane są wskaźniki kapitału intelektualnego jako miary zasobu niematerialnego, przy czym uważa się, iż zawiera on trzy podstawowe wskaźniki:

- kapitał ludzki,

- kapitał strukturalny,

- kapitał kliencki. 
Jako pozycja dominująca wśród aktywów organizacji - kapitał intelektualny wymaga jednak wskazania najistotniejszych kryteriów oceny. Za propagatora idei organizacji uczących się uważany jest Peter Senge ${ }^{4}$. Uważał on, że najważniejszą cechą organizacji inteligentnej jest umiejętność uczenia się i wykorzystywania wiedzy. W aspekcie umiejętności wykorzystywania zasobów wiedzy nabytej poprzez organizację można sformułować kryteria, które odnoszą działania w przedsiębiorstwie do jej zasobów wiedzy z transpozycją przyszłego rozwoju:

- Występowanie w organizacji procesów projektowania i budowania wspólnej wizji przyszłości, która umożliwia pracownikom identyfikowanie się z organizacją i zachęca do podejmowania wyzwań.

- Systemowe myślenie w firmie polegające na tym, że każdy pracownik dostrzega, iż nie jest tylko malutkim elementem systemu, ale jest jego odbiciem, które ma wpływ na wszystko, co się dzieje w firmie.

- Kodeks etyki - przejawiający się w tworzeniu kultury organizacji, wpływający na poprawę relacji zarówno wewnątrz firmy jak i poprawę relacji pomiędzy partnerami.

- Firma uczy się poprzez uczenie się jednostek - to jest wszystkich pracowników. Pracownicy dążą do mistrzostwa osobistego w zakresie swoich obowiązków oraz ciągle się rozwijają. Efekty tychże dążeń mogą być zestawione następująco jako atrybuty organizacji inteligentnej:

- Otwarte modele myślowe - pracownicy zdają sobie sprawę z otaczającej ich rzeczywistości, widzą konieczność odejścia od stereotypów i bycia otwartym na innowacje. Innowacje są szczególnie istotne w przemyśle farmaceutycznym. Świadomość ta przyczynia się do rozwoju osobistego i organizacyjnego.

- Zespołowe uczenie się ma miejsce w całej organizacji i przejawia się wspólnymi dyskusjami i rozwiązywaniem problemów.

Cechą charakterystyczną organizacji inteligentnej jest umiejętność wykorzystania posiadanej wiedzy dla jej rozwoju. Implementacja wiedzy przejawia się w postaci realizacji procesów innowacyjnych kreowanych w przedsiębiorstwie (Janczewska 2010: 107), których dynamika i rodzaje są powiązane $\mathrm{z}$ istniejącymi w przedsiębiorstwie zasobami kapitału intelektualnego. Zdaniem Anny Wziątek-Kubiak zasoby wiedzy w przedsiębiorstwie są unikalne w odniesieniu do miejsca akumulowania wiedzy i są trudne do transferowania poza dane przedsiębiorstwo (Wziątek-Kubiak 2009: 4). Pozostają zatem jej indywidualnym zasobem, który nie podlega transferowaniu poza obszar organizacji ${ }^{5}$. Zróżnicowanie zasobów wiedzy między poszczególnymi przedsiębiorstwami i umiejętności ich wykorzystania w walce konkurencyjnej dają przedsiębiorstwom możliwość osiągania lepszych pozycji rynkowych.

Nakłady na działalność B+R uważane są za wskaźnik charakteryzujący potencjał wiedzy w danym kraju oraz zdolność do kreowania innowacji. Założenia realizacji celu budowy Gospodarki Opartej na Wiedzy (GOW) kształtują ten wskaźnik w Polsce i pozostałych

${ }^{4}$ Koncepcje organizacji uczącej się przedstawił Peter Senge w książce Piąta dyscyplina. Teoria i praktyka organizacji uczacych się, Wolters Kluwer, Warszawa 2012.

${ }^{5}$ Można polemizować z tym poglądem, biorąc pod uwagę szerokie możliwości transferu wiedzy poza organizację poprzez migrację pracowników, przekazywanie informacji i elementów indywidualnej wiedzy wewnatrzorganizacyjnej w sposób otwarty lub niedozwolony. 
krajach Unii Europejskiej docelowo na poziomie 2\% PKB. Obecny poziom nakładów na $\mathrm{B}+\mathrm{R}$ w Polsce podawany przez GUS wynosi $0,3 \%$ - co wskazuje na duże braki w tej dziedzinie w stosunku do krajów unijnych (Kozłowski 2011). Dane dotyczące innowacji są zestawiane w GUS w układzie gałęziowym na podstawie sprawozdań (PNT-02 - sprawozdanie o innowacjach w przemyśle) i publikowane w Rocznikach Statystycznych ogólnych oraz w specjalistycznych raportach, np. „Nauka i technika w liczbach”.

Według UNCTAD za transfer wiedzy uważa się „transfer systematycznej wiedzy dla wytworzenia produktu, zastosowania procesu lub wykonania usług, lecz nie obejmuje transakcji ograniczających się wyłącznie do sprzedaży, czy wynajmu dóbr” (UNCTAD 2001). UNCTAD kładzie nacisk na wiedzę służącą kreowaniu produktów i usług - co z kolei w pewien sposób zawęża zasięg oddziaływania wiedzy rozumianej jako źródło inspiracji do tworzenia nowej wiedzy, nie tylko praktycznych implementacji. OECD definiuje kanały transferu wiedzy (OECD 2005) w postaci ucieleśnionej (ludzie, sprzęt, materiały, urządzenia) lub nieucieleśnionej (dokumenty, informacja pisana). Badania prowadzone przez Instytut Badań Strukturalnych w Polsce wskazują na cztery kierunki przepływu wiedzy (Bukowski, Szpor, Śniegocki 2012: 26):

- przepływ wiedzy pomiędzy przedsiębiorstwami wewnątrz sektora prywatnego,

- przepływ wiedzy między sektorem publicznym i prywatnym,

- dyfuzja innowacji usprawniających dzięki zakupom nowatorskich dóbr i usług,

- dyfuzja „cichej wiedzy” (tacit knowledge) dzięki mobilności pracownika.

Transfer wiedzy może być rozpatrywany w ujęciu procesowym, jako przepływ wiedzy szeroko pojętej z ośrodków kreowania wiedzy do organizacji absorbujących wiedzę. Transfer wiedzy jest procesem korzystnym zarówno dla firm uczestniczących w procesie przepływu wiedzy, jak również dla gospodarki danego kraju - ze względu na możliwość przekształcenia wiedzy w innowacje. Jasiński powołuje się na nowe pojęcia i koncepcje transferu wiedzy np. pojęcie exnovation (Jasiński 2007: 28), które oznacza rozwój techniczny w kraju odbiorcy pod pływem transferu techniki w kraju dostawcy. Proces transferu wiedzy zapoczątkowuje działalność innowacyjną, której efekty są powiązane z rodzajem wiedzy oraz kierunkami jej przepływu (Białoń, Janczewska 2007). Stosowane obecnie zgodnie z nomenklaturą Oslo Manual wskaźniki działalności innowacyjnej dotyczą między innymi:

- w dziedzinie innowacji technologicznych: statystyki dotyczącej udziału w badanej populacji firm, które wprowadziły w ostatnich latach jakąkolwiek innowację produktową lub procesową,

- w dziedzinie innowacji nie-technologicznych: udział firm, które wprowadziły jakiekolwiek innowacje marketingowe lub organizacyjne,

- nakłady na B+R: jako ogólne wydatki na działalność badawczo-rozwojową,

- efekty (output) innowacji na wyniki sprzedaży, na koszty i zatrudnienie, wpływ innowacji na wydajność i produktywność,

- cele i przeszkody innowacji : czynniki kosztowe, rynkowe, czynniki wiedzy.

Badania GUS w zakresie innowacyjności w sektorze mikroprzedsiębiorstw w ujęciu wskaźników statystycznych są poddawane krytyce, ze względu na trudności w określeniu i ocenie badanego zjawiska. Szczególnie trudne jest oszacowanie wpływu danej innowacji na 
rozwój mikroprzedsiębiorstwa, gałęzi, czy sektora. Kwestionariusze badania nie uwzględniają istoty i specyfiki działalności innowacyjnej w danym mikroprzedsiębiorstwie - co utrudnia przeprowadzenie analiz, czy ocen porównawczych. W sektorze mikroprzedsiębiorstw trudno jest wskazać przykłady innowacji radykalnych, wymagających specjalistycznego zaplecza aparaturowego i technicznego. Trudno nieraz (bez dłuższej perspektywy czasu) odróżnić drobne usprawnienie od istotnej, a nawet radykalnej innowacji. Innowator wprowadzający jako pierwszy wynalazek na rynek nie jest w stanie przewidzieć skali jego dyfuzji, udoskonaleń i przyszłych zastosowań. Dostępne dane i wskaźniki charakterystyczne dla działalności innowacyjnej posiadają istotne nieścisłości i stanowią o niepełnym obrazie innowacji (Kozłowski 2011: 105). Najczęściej spotykane wskaźniki charakteryzują się następująco:

- nie pokazują natury innowacji, w jaki sposób nakłady w postaci wkładu pieniężnego oraz wkładu pracy przekształciły się w materialny i skomercjalizowany efekt innowacji,

- nic nie mówią o ekonomicznej efektywności tego procesu,

- są obarczone dużym stopniem subiektywizmu (co do tego, czy zmiana kwalifikuje się do określenia jej jako innowacji, czy nie).

Badania działalności innowacyjnej prowadzone przez GUS koncentrują się na przemyśle przetwórczym, podczas gdy sektor MŚP i mikroprzedsiębiorstwa w większości prowadzą działalność usługową i handlową. Wskaźniki statystyczne nie uwzględniają poszczególnych faz procesu innowacyjnego, w tym fazy komercjalizacji, często decydującej o powodzeniu i sukcesie idei innowacyjnej. Sama konstrukcja kwestionariuszy w krajach Unii Europejskiej uniemożliwia dokonywanie porównań pomiędzy poszczególnymi krajami - pozostawiając jedynie dane bezwzględne GERD jako obszar porównań. Badania przepływu wiedzy i innowacyjności gospodarki prowadzone przez Ministerstwo Gospodarki potwierdzają niedostateczny udział sektora mikroprzedsiębiorstw w transferze wiedzy oraz przekształcaniu wiedzy $\mathrm{w}$ innowacje.

\section{ABSORPCJA WIEDZY W SEKTORZE MŚP}

W roku 2009 liczba zarejestrowanych przedsiębiorstw MŚP w Polsce wynosiła 3880 tys., z czego 94,7\% stanowiły przedsiębiorstwa mikro, zatrudniające do 9 osób. Firmy małe stanowiły $4,4 \%$, a średnie $0,8 \%$. W ujęciu strukturalnym jedynie $11 \%$ firm w sektorze MŚP stanowiły firmy produkcyjne, natomiast $89 \%$ przedsiębiorstw deklarowało działalność usługową. Udział sektora MŚP w tworzeniu PKB w roku 2008 wynosił 46,9\% (PARP 2010: 29). Zarówno liczba przedsiębiorstw MŚP, jak i ich udział w tworzeniu dochodu narodowego wskazują na ich zasadnicze znaczenie dla rozwoju gospodarki. Rozwój gospodarczy związany jest z budową GOW - gospodarki opartej na wiedzy (Knowledge-Based Economy), a w perspektywie celów Unii Europejskiej do roku 2020 - głównym celem jest kreowanie przedsiębiorstwa inteligentnego, uczącego się. Powstaje zatem pytanie, czy sektor MŚP można analizować w aspekcie cech przedsiębiorstwa uczącego się oraz jakie kategorie uwarunkowań mogą stymulować rozwój przedsiębiorstwa MŚP. 
Istotnym czynnikiem, który należy przeanalizować omawiając transfer wiedzy ze sfery nauki do sektora MŚP jest kwestia możliwości absorpcyjnych, inaczej mówiąc wiedzochłonności sektora MŚP. Problematyka wiedzochłonności w ujęciu gałęzi przemysłu była już przedmiotem badań (Białoń, Janczewska 2009). W analizie tej podkreśla się brak danych dotyczących sfery usług oraz danych dotyczących przedsiębiorstw mikro. Niska wiedzochłonność polskich przedsiębiorstw pozwala na konkluzję, iż nie są one zainteresowane rozwijaniem tzw. pierwiastka intelektualnego w innowacjach.

Pierwiastek intelektualny jest pojęciem agregatowym. W różnych organizacjach występują takie jego elementy, jak:

- wiedza potrzebna do realizowania działalności rozwojowej wszelkich form aktywności ludzkiej,

- ciągłe uzupełnianie i nabywanie nowej wiedzy i nowych umiejętności i wiadomości,

- tworzenie własnego zaplecza badawczo-rozwojowego,

- wprowadzanie nowych projektów i usprawnień organizacyjnych,

- projektowanie nowych technologii,

- korzystanie z opracowań ze sfery B+R.

Szansą na rozwój przedsiębiorstwa jest poszukiwanie dostępu do wiedzy, wprowadzanie innowacji technologicznych, technicznych i organizacyjnych ${ }^{6}$ oraz wdrażanie strategii zarządzania innowacjami. Zainteresowanie MŚP wdrażaniem innowacji nie jest duże (Sosnowska, Łobejko 2006: 7) stąd też szczególna rola w umożliwieniu dostępu do wiedzy MŚP przypada uczelniom oraz jednostkom nauki, które powinny zbliżyć się zarówno do problematyki przemysłowej, jak i nawiązywać bezpośrednie kontakty z przedsiębiorcami z grupy MŚP ${ }^{7}$. Współcześnie dominuje teoria o możliwości budowania przewagi konkurencyjnej przedsiębiorstw z sektora MŚP na czynnikach niematerialnych, głównie związanych z kwalifikacjami i kompetencjami pracowników. W odniesieniu do sektora MŚP podnoszenie konkurencyjności uwarunkowane jest możliwością realizacji procesu budowania zasobów wiedzy w przedsiębiorstwach z sektora MŚP oraz przekształcania przedsiębiorstwa w organizację inteligentną.

Badania prowadzone przez PARP w latach 2008-2009 wskazały na kluczowe umiejętności i znaczenie zasobów wiedzy niezbędnej w prowadzeniu własnego przedsiębiorstwa (PARP 2010: 185, 189). Wyszukiwanie informacji strategicznych, przekształcanie ich W wiedzę niezbędną do prowadzenia przedsiębiorstwa nie jest zjawiskiem powszechnym wśród MŚP według badań PARP. Około 17\% badanych MŚP w ogóle nie poszukiwało i nie korzystało z żadnego typu informacji strategicznych. W opinii badanych najczęściej poszukiwaną informacją jest ta, która umożliwia kontynuowanie działalności dotychczasowej oraz wskazuje sposoby zarabiania pieniędzy. Wśród najważniejszych umiejętności, które należy kształcić przedsiębiorcy wskazywali: wiedzę na temat pozyskiwania funduszy na

${ }^{6}$ Szerzej na temat wpływu innowacji na rozwój przedsiębiorstw wypowiada się M.E. Porter w książce Przewaga konkurencyjna. Osiaganie i utrzymywanie lepszych wyników, Wydawnictwo Helion, Gliwice 2006, s. 211.

${ }^{7}$ L. Palmen, M. Baron w pozycji Rola wyższych uczelni w procesie budowy Gospodarki Opartej na Wiedzy, referat na Konferencji RIS-Silesia, Katowice, 27.10.2005, przedstawiają pogląd, iż wyższe uczelnie mają zadanie inicjowania transferu wiedzy do sfery przemysłu. 
prowadzenie firmy, umiejętność tworzenia strategii firmy, znajomość technik tworzenia biznesplanów, technik marketingowych, analizy potrzeb klientów, reklamy, sprzedaży, wiedza na temat wymogów i przepisów prawnych na temat prowadzenia firmy, umiejętność prowadzenia negocjacji. Inne badania PARP prowadzone w roku 2009 dotyczące znaczenia informacji strategicznych w działalności przedsiębiorstw dowiodły, że przedsiębiorcy z sektora MŚP poszukują informacji, które mogą wpłynąć na strategię przedsiębiorstw oraz korzystają $\mathrm{z}$ informacji o nowych technologiach, nowych klientach, konkurentach oraz o aktualnych klientach. Niewielka grupa badanych wskazywała też na poszukiwanie informacji o otoczeniu międzynarodowym firmy. Badania PARP nad innowacyjnością sektora mikroprzedsiębiorstw wykazały niewielkie zainteresowanie poszukiwaniem wiedzy (Juchniewicz, Grzybowska 2010: 10-141).

\section{DZIAŁANIA LOGISTYCZNO-MARKETINGOWE W PROCESIE TRANSFERU WIEDZY W SEKTORZE MIKROPRZEDSIĘBIORSTW}

Z punktu widzenia mikroprzedsiębiorstwa, działania logistyczno-marketingowe w procesie transferu wiedzy powinny wspomagać zarówno sam proces, jak i rozwój poszczególnych elementów kapitału wiedzy:

- w obszarze kapitału ludzkiego działania logistyczno-marketingowe będą dotyczyć poszukiwania pracowników posiadających odpowiednie wykształcenie, wymagane przez przedsiębiorstwo umiejętności. Metody marketingowe powinny ułatwiać rozpoznanie zakresu zapotrzebowania na pracowników, natomiast logistyka pozyskiwania kapitału ludzkiego ma za zadanie dynamiczne kumulowanie specjalistów niezbędnych do rozwiązywania problemów mikroprzedsiębiorstwa,

- w obszarze kapitału strukturalnego analizy marketingowe posłużą do oceny mocnych stron przedsiębiorstwa, jego oferty rynkowej oraz poprzez zarządzanie procesami logistycznymi zapewnią doskonalenie kapitału organizacyjnego,

- w obszarze kapitału klienckiego działania marketingowe powinny wspierać budowanie relacji z klientami poprzez stosowanie logistycznych metod zarządzania tymi relacjami.

Zamiast kapitału klienckiego inni badacze stosują określenie „struktura zewnętrzna” oraz „struktura wewnętrzna”. Obszary kapitału intelektualnego przedsiębiorstwa stają się wartością finansową, jeżeli przedsiębiorstwo potrafi je wykorzystać w celu wzrostu zasobów wiedzy, poprawy pozycji konkurencyjnej i finansowej. Należy jednak zauważyć, że kapitał intelektualny jako wartość nie pasuje do tradycyjnego modelu rachunkowości przedsiębiorstw ze względu na niedocenianie zasobów niematerialnych w kanonach tradycyjnej rachunkowości (Czechowska-Świtaj 2005: 44). Jednocześnie podkreślany jest wpływ kultury organizacyjnej na kreowanie kapitału intelektualnego w przedsiębiorstwie oraz na wzrost zasobów niematerialnych w tymże przedsiębiorstwie (Sułkowski 2012: 22).

$\mathrm{Z}$ punktu widzenia jednostek sfery nauki, wspieranie logistyczno-marketingowe procesu transferu wiedzy do mikroprzedsiębiorstw powinno łączyć się z następującymi działaniami: 
- prowadzenie marketingowych analiz zapotrzebowania na wiedzę ze strony potencjalnych odbiorców, w tym mikroprzedsiębiorstw,

- formułowanie ofert wiedzy spełniających oczekiwania odbiorców,

- dobór instrumentów marketingu - mix właściwych dla wiedzy jako „towaru”,

- identyfikacja i segmentacja odbiorców wiedzy,

- budowanie rynku transferu wiedzy,

- badanie chłonności na wiedzę sektora mikroprzedsiębiorstw oraz poszczególnych segmentów rynku transferu wiedzy,

- wybór optymalnych kanałów transferu wiedzy, możliwych do zaakceptowania przez odbiorców,

- kontrolowanie dynamiki przepływu wiedzy ze sfery nauki do przemysłu,

- dobór metod i środków stymulujących dynamikę przepływu wiedzy.

Źródłem informacji dla pracowników w przedsiębiorstwie mogą być:

- źródła pierwotne: książki, czasopisma, patenty, opublikowane raporty, normy, specyfikacje, ustawy, wewnętrzne raporty przedsiębiorstw, projekty techniczne i referaty naukowe (Pomykalski 2001: 185),

- źródła wtórne: czasopisma abstraktów, informatory o publikacjach,

- obserwacje,

- konsultacje,

- powiadomienia o osiągnięciach naukowo-badawczych,

- udział w przedsięwzięciach $\mathrm{B}+\mathrm{R}$.

Zarówno działania marketingowe, jak i procesy przepływu informacji wspomagają dobór źródeł informacji, jak i samo ich wykorzystanie. Udział we wspólnych przedsięwzięciach z udziałem sfery nauki jest dla przedsiębiorstw z sektora MŚP dostępny, ze względu na specjalne projekty innowacyjne, w których współpraca innowacyjna firm MŚP i instytucji naukowych są finansowane przez Unię Europejską. Inwestycją w wiedzę są zatem wydatki na działalność badawczo-rozwojową (B+R), zakup know-how, licencji i technologii. Wiedzochłonność przedsiębiorstwa lub branży może być definiowana poprzez nakłady finansowe przeznaczone na działalność innowacyjną (Białoń, Janczewska 2007).

\section{TRANSFER WIEDZY W SEKTORZE MIKROPRZEDSIĘBIORSTW}

NA PRZYKŁADZIE BRANŻY KONSTRUKCJI SPAWANYCH

Przykładem doskonalenia procesu przepływu wiedzy w przedsiębiorstwie może być systemowe podejście do podnoszenia poziomu wiedzy w przedsiębiorstwie w branży konstrukcji spawanych z sektora MŚP ${ }^{8}$. Badania własne mikroprzedsiębiorstw w sektorze konstrukcji spawanych prowadzone były przez autorkę w latach 2007-2009. Badaniami objęto 50 przedsiębiorstw z sektora MŚP, wśród których 10\% stanowiły przedsiębiorstwa mikro zlokalizowane na terenie woj. łódzkiego, mazowieckiego i kujawsko-pomorskiego. Dobór

\footnotetext{
${ }^{8}$ Przedsiębiorstwo z sektora MŚP - producent konstrukcji stalowych spawanych.
} 
próby był celowy i dotyczył przedsiębiorstw uczestniczących w projekcie budowy elektrowni wiatrowych dla odbiorcy zagranicznego. Głównym celem badań była identyfikacja metod zarządzania w badanej grupie przedsiębiorstw, w tym metody zarządzania wiedzą. Wyodrębniono zagadnienie transferu wiedzy w badanych przedsiębiorstwach oraz elementy budowy kapitału intelektualnego w poszczególnych przedsiębiorstwach. W wyniku badań zdefiniowano proces transferu wiedzy oraz jego etapy:

- pierwszym etapem procesu transferu wiedzy w badanych przedsiębiorstwach w branży konstrukcji metalowych było pozyskanie specjalistów, którzy stali się inicjatorami dalszego gromadzenia zasobów wiedzy.

- drugi etap uzupełniania i zdobywania wiedzy następował w wyniku decyzji właścicieli i polegał na permanentnym uczeniu się poprzez udział w kursach i szkoleniach. Kadra menedżerska uczestniczyła też w spotkaniach z dostawcami, z innymi producentami w branży i z firmami współpracującymi, których celem było poznanie nowych technik i technologii, ale także metod zarządzania, marketingu, etc.

- trzeci etap procesu transferu wiedzy polegał na implementacji zdobytej wiedzy w praktyce. Powołano laboratorium zakładowe oraz stworzono zaplecze techniczno-technologiczne dla celów projektowych, czy prób w skali laboratoryjnej.

- czwarty etap wiązał się z pracą nad nowymi projektami i usprawnieniami organizacyjnymi oraz projektowaniem nowych technologii, rozpoczęto również prace nad tworzeniem zakładowego systemu zarządzania jakością.

- ostatnim etapem w procesie budowania kapitału intelektualnego było poszukiwanie możliwości współpracy z ośrodkami nauki ze względu na konieczność zaprojektowania i wykonania specjalistycznych badań jakościowych konstrukcji stalowych.

Efektem końcowym i wartością dodaną w procesie transferu wiedzy w mikroprzedsiębiorstwie był wzrost zasobów wiedzy - w postaci zdobytych informacji, doświadczeń oraz pojawienia się $\mathrm{w}$ przedsiębiorstwie potrzeby prowadzenia działań naukowo-badawczych we współpracy z jednostką naukową. W mikroprzedsiębiorstwie został utworzony system permanentnego kształcenia pracowników, na wszystkich stanowiskach. Tematem szkoleń były bieżące problemy związane z jakością produkcji, doskonaleniem procesów logistycznych oraz wprowadzaniem nowych metod marketingowych. Jedną z bardziej nowoczesnych form transferu wiedzy w mikroprzedsiębiorstwie było powołanie interdyscyplinarnego zespołu, którego celem było projektowanie nowych wyrobów. Proces opracowania nowego produktu pokazuje rys. 1. Przedsiębiorstwo odeszło od tradycyjnej koncepcji powierzenia zadania opracowania nowych wyrobów technologowi, czy kierownikowi produkcji. Celem stworzenia takiej struktury zespołu była wymiana zasobów wiedzy zlokalizowanych w poszczególnych działach organizacyjnych przedsiębiorstwa oraz wykreowanie nowych metod zarządzania innowacyjnego $\mathrm{w}$ przedsiębiorstwie. Po wprowadzeniu nowego logistyczno-marketingowego systemu, proces opracowania nowego produktu został skrócony z 1 miesiąca do 10 dni i prowadzony był w zespole wieloosobowym, w którym wszyscy uczestnicy mieli prawo wygłaszania swoich poglądów oraz koncepcji. Dział marketingu przedstawił wyniki badania nabywców i wskazał na najważniejsze sugestie i oczekiwania wobec nowego produktu: smak, wygląd, rodzaj opakowania, forma dystrybucji oraz perspektywy 
sprzedaży nowego produktu. Podczas spotkań zespołu przeprowadzono dyskusje nad nowymi rozwiązaniami, możliwościami pozyskania surowców, opakowań oraz sposobem doboru firm kooperujących. Dział produkcji określił możliwości techniczne, technologiczne oraz przewidywane trudności i komplikacje w procesie produkcji. Rola działu księgowości polegała na określeniu możliwości finansowych zakładu i wyrażeniu opinii na temat kalkulacji cenowej produktu i rachunku kosztów wytworzenia i dystrybucji nowego produktu. Efektem zastosowanego prezentowanego powyżej sposobu organizacji procesu tworzenia nowego produktu był wzrost zasobów wiedzy w całej organizacji, w poszczególnych jej działach, powiększony o wiedzę przekazaną w trakcie dyskusji i narad przez innych pracowników spoza grupy projektowej. Dodatkowym efektem synergicznym było powstanie nowych zasobów wiedzy wśród pozostałych pracowników przedsiębiorstwa, biorących udział w dyskusji czy zgłaszających własne koncepcje i pomysły. Kanałem transferu wiedzy w przedsiębiorstwie był również intranet, który przyspieszał wymianę informacji, czy też umożliwiał szybką wymianę zapisów, wyliczeń, wzorów konstrukcyjnych lub nowych zamówień od klientów. W procesie transferu wiedzy zaznaczyły się czynniki marketingowe oraz logistyczne, które stymulowały proces.

Model logistyczno-marketingowego systemu transferu wiedzy w mikroprzedsiębiorstwie pokazany został na rys. 1 .

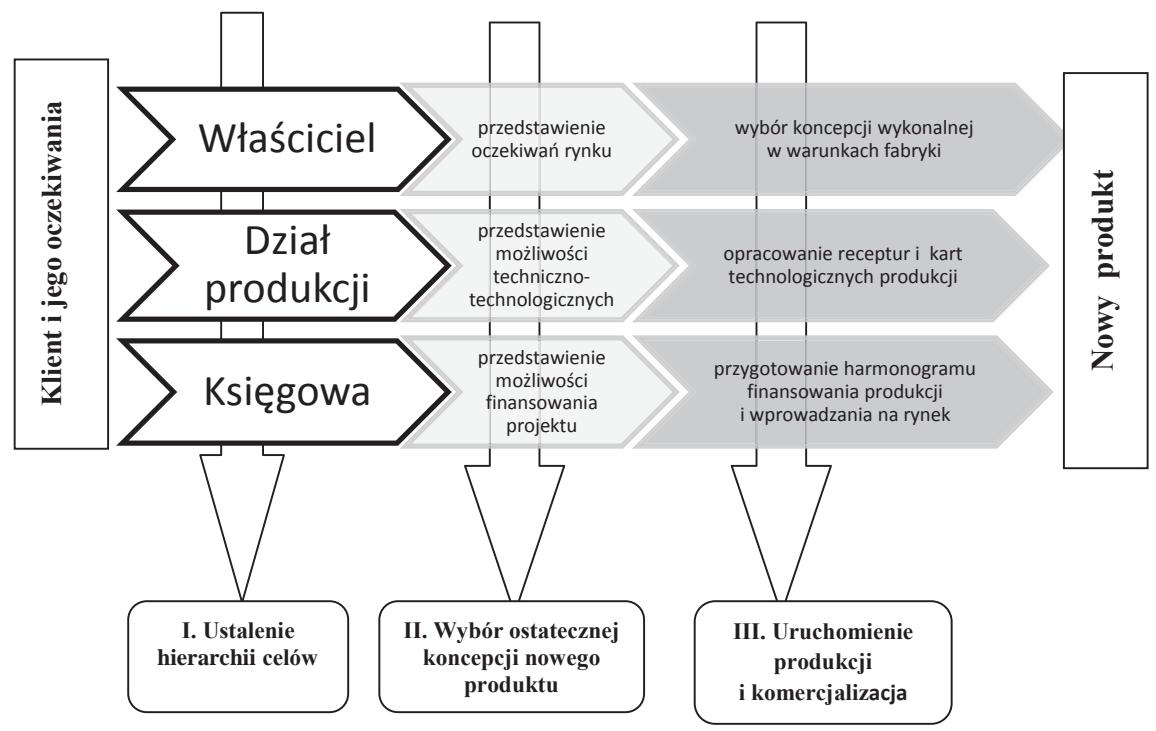

Rys. 1. Proces opracowania nowego produktu w zespole interdyscyplinarnym w przedsiębiorstwie uczącym się na przykładzie mikroprzedsiębiorstwa z branży konstrukcji spawanych

Źródło: opracowanie własne

Badani mikroprzedsiębiorcy wskazywali na najważniejsze czynniki marketingowo-logistyczne, wśród których znalazły się: 
- prowadzenie marketingowych analiz zapotrzebowania na wiedzę ze strony potencjalnych odbiorców, w tym mikroprzedsiębiorstw,

- formułowanie ofert wiedzy spełniających oczekiwania odbiorców,

- dobór instrumentów marketingu - mix właściwych dla wiedzy jako „towaru”,

- identyfikacja i segmentacja odbiorców wiedzy,

- budowanie rynku transferu wiedzy,

- badanie chłonności na wiedzę sektora mikroprzedsiębiorstw oraz poszczególnych segmentów rynku transferu wiedzy,

- wybór optymalnych kanałów transferu wiedzy, możliwych do zaakceptowania przez odbiorców,

- kontrolowanie dynamiki przepływu wiedzy ze sfery nauki do przemysłu,

- dobór metod i środków stymulujących dynamikę przepływu wiedzy.

Wybór działań zwiększających dynamikę transferu wiedzy oraz wzrost zasobów kapitału intelektualnego w przedsiębiorstwie obejmuje podnoszenie poziomu wykształcenia pracowników, ocenę i ekspertyzę działań technologicznych oraz rozwój relacji z klientami. Rezultaty podjętych działań w obszarze transferu wiedzy były oceniane poprzez pomiar satysfakcji, lojalności, doświadczeń nabytych podczas realizacji działań oraz pomiar wzrostu wartości przedsiębiorstwa.

\section{Podsumowanie}

Uwarunkowania transferu wiedzy w sektorze mikroprzedsiębiorstw jest zagadnieniem rzadko spotykanym w literaturze przedmiotu. Sektor mikro firm nie jest traktowany jako sektor innowacyjny, zdolny do kreowania nowych produktów czy procesów, a same badania zjawisk występujących w sektorze trwają od niedawna i mają głównie charakter poszukiwania wskaźników ilościowych. Przedsiębiorcy działający w sektorze mikro są postrzegani jako osoby nieposiadające strategii rozwoju własnych firm, niechętnie wprowadzające innowacje czy poszukujące informacji. Wskazywanie możliwości rozwoju przedsiębiorstwa mikro w kierunku budowania zasobów wiedzy jest uzasadnione zarówno ze względu na dostępność wiedzy, jak i możliwości dofinansowania czy udziału w programach unijnych. Przykłady przedsiębiorstw z branży konstrukcji spawanych potwierdzają, iż w badanych mikroprzedsiębiorstwach podejmowane są inicjatywy w zakresie budowania zasobów wiedzy. Czynnikiem dynamizującym proces transferu wiedzy jest stosowanie logistyczno-marketingowych działań w mikroprzedsiębiorstwach. 


\section{Literatura / References}

Białoń, L., Janczewska, D. (2007). Wiedzochłonność procesów innowacyjnych, cz. I, Postepy Techniki Przetwórstwa Spożywczego, Nr 2/2007, t. 17/31, 93-97.

Bielecka, A. (2005). Zarządzanie wiedzą w sektorze MSP. W: J. Szabłowski (red.), Strategie rozwoju małych i średnich przedsiębiorstw w otoczeniu metropolii warszawskiej. Otwock: Wyd. Wyższa Szkoła Przedsiębiorczości i Nauk Społecznych w Otwocku.

Bukowitz, W.R., Wiliams, R.L., (2000). The Knowledge Management Fieldbook. London: Financial Time.

Bukowski, M., Szpor, A., Śniegocki, A. (2012). Potencjat i bariery polskiej innowacyjności. Warszawa: Wyd. Instytut Badań Strukturalnych.

Czechowska-Świtaj, T. (2005). Zarządzanie kapitatem intelektualnym $w$ organizacji. Warszawa: Oficyna Wydawnicza Wyższej Szkoły Menedżerskiej.

Edvinsson, L., Malone, M.S. (2001). Kapitat intelektualny. Warszawa: Wydawnictwo Naukowe PWN.

Grudzewski, W., Hejduk, I. (1999). Kreowanie przedsiębiorstwa przyszłości z wykorzystaniem teorii i praktyki organizacji inteligentnej. W: M. Haffer, S. Sudoł (red.), Przedsiębiorstwo wobec wyzwań przyszłości. Toruń: Wyd. Komitet Nauk Organizacji i Zarządzania PAN, Uniwersytet Mikołaja Kopernika, Wydział Nauk Ekonomicznych i Zarządzania.

Janczewska, D. (2010). Podnoszenie konkurencyjności MŚP poprzez transfer wiedzy z jednostek nauki do zastosowań praktycznych w regionie. W: J. Wernik, K. Wołosz (red.), Szkoły wyższe w gospodarce regionów. Warszawa: Wyd. Oficyna Wydawnicza Politechniki Warszawskiej.

Jasiński, A.H., Ludwicki, D. (red.) (2007). Raport PW-002, Metodyka transformacji wyników badań naukowych do zastosowań praktycznych. Studia i Materiały Wydz. Zarządzania UW, Warszawa, Nr 1/2007, 25-66.

OECD (1997). Technology and Industrial Performance. Paris.

Palmen, L., Baron, M. (2005). Rola wyższych uczelni w procesie budowy Gospodarki Opartej na Wiedzy, referat na Konferencji RIS-Silesia, Katowice, 27.10.2005.

PARP (2010). Raport o stanie sektora matych i średnich przedsiębiorstw w Polsce $w$ latach 20082009. Warszawa: Wydawnictwo PARP.

Penc, J. (2000). Menedżer w uczącej się organizacji. Łódź: Wyd. Menedżer.

Pietruszka-Ortyl, A. (2002). Model diagnozy kapitału intelektualnego organizacji. W: B. Mikuła, A. Pietruszka-Ortyl, A. Potocki (red.), Zarzadzanie przedsiębiorstwem XXI wieku. Warszawa: Wyd. Difin.

Plawgo, B. (2010). Wyksztatcenie pracowników a konkurencyjność przedsiębiorstwa - Referat wygłoszony na konferencji PARP, Warszawa, 16.11.2010.

Pomykalski, A. (2001). Zarzadzanie innowacjami. Warszawa: Wydawnictwo Naukowe PWN.

Porter, M.E. (2006). Przewaga konkurencyjna. Osiaganie i utrzymywanie lepszych wyników. Gliwice: Wydawnictwo Helion.

Probst, G., Raub, S., Romhardt, K. (2002). Zarządzanie wiedza w organizacji. Kraków: Oficyna Ekonomiczna.

Senge, P. (2012). Piąta dyscyplina. Teoria i praktyka organizacji uczących się. Warszawa: Wolters Kluwer.

Sosnowska, A., Łobejko, S. (2006). Małe i średnie polskie przedsiębiorstwa w warunkach konkurencji. Pozytywy i trudności w rozwoju. Warszawa: Wyd. PARP. 
Steward, T.A. (1997). Intellectual Capital - The Wealth of New Organization. London: Nicholas Breadley Publishing.

Sułkowski, Ł. (2012). Wieloznaczność kultury organizacyjnej. W: J. Woroniecki, Ł. Prysiński (red.), Szanse i zagrożenia rozwoju przedsiębiorczości - aspekty rachunkowe, finansowe i organizacyjne. Łódź: Wyd. Społeczna Akademia Nauk.

UNCTAD (2001). Compendium of international arrangements on transfer of technology. New York: United Nations.

Weresa, M. (2007). Wiedza jako przedmiot transferu do biznesu. W: M. Weresa (red.), Transfer wiedzy z nauki do biznesu - doświadczenia regionu Mazowsze. Warszawa: Wyd. SGH.

Wziątek-Kubiak, A. (2009). Od awersji do upowszechnienia się innowacji wśród polskich przedsiębiorstw. W: E. Adamowicz (red.), Polska transformacja po latach. Warszawa: Wyd. C.H. Beck.

Danuta Janczewska, dr inż., Społeczna Akademia Nauk w Łodzi.

Adiunkt w Katedrze Marketingu i Logistyki na Wydziale Zarządzania Społecznej Akademii Nauk w Łodzi. Jej zainteresowania naukowe i publikacje dotyczą dziedziny nauk o zarządzaniu: marketingu i logistyki - w aspekcie problematyki zarządzania jakością, wiedzą i innowacjami w przedsiębiorstwach z sektora MŚP.

Danuta Janczewska, Dr. Ing., Senior Lecturer in Department of Marketing and Logistics of Social Academy of Science in Lodz. Research interests and numerous publications within the scope of Management science: marketing and logistics, with respect to quality management, knowledge and innovation in SMEs sector.

adres/address: Społeczna Akademia Nauk w Łodzi

ul. Sienkiewicza 9, 90-113 Łódź, Polska

e-mail: janczewska@republika.pl 